\title{
P055: Roommates' colonization rates for multiresistant bacteria in a tertiary care hospital
}

\author{
MJ Torijano, F Grande, M Cantero, M Grande, V Nováková, P Rodríguez \\ From 2nd International Conference on Prevention and Infection Control (ICPIC 2013) \\ Geneva, Switzerland. 25-28 June 2013
}

\section{Introduction}

Multiresistant-bacteria infection control measures in hospitals may include screening of patients at high risk of colonization, patients who are admitted to high-risk wards, patients submitted to high-risk procedures, roommates of patients with colonized or infected patients and screening during outbreaks.

\section{Objectives}

To study the rate of multiresistant bacteria colonization in roommates of patients infected or colonized by multiresistant microorganisms.

\section{Methods}

Retrospective observational study of smears collected from roommates of multiresistant-bacteria positive patients between 2010 and 2012. Percentages and 95\% confidence intervals (CI95\%) were calculated.

\section{Results}

Altogether, 3306 roommates samples were collected, out of which 172 were positive (rate 5,20\% (CI95\%: 4,43$5,97)$ ). Rates for MRSA were 6,50\% (CI95\%:5,14-7,86), extended-spectrum beta-lactamase-producing bacteria 4,33\%(CI95\%:3,3-5,36), and Acinetobacter baumanii multiresistant 4,48\% (CI95\%: 1,54-7,42), Carbapenemase-producing bacteria 1,85\% (C195\%: 0,22-6,53). Rates along the study period were: 2010, 4,56\% (IC95\%: 3,505,62), 2011 (CI95\%: 5,21-8,52) and 2012 3,82\% (CI95\%: $2,58-5,10)$.

\section{Conclusion}

The percentage of positive samples in roommates of patients colonized or infected by multiresistant bacteria was relatively low during the studied period. However,

Preventive Medicine and Quality Management, General University Hospital Gregorio Marañón, Madrid, Spain further studies are needed to compare colonization rates between these roommates and other hospitalised patients to study if colonization can be due to sharing room in hospitals or not.

\section{Disclosure of interest}

None declared.

Published: 20 June 2013

doi:10.1186/2047-2994-2-S1-P55

Cite this article as: Torijano et al:: P055: Roommates' colonization rates for multiresistant bacteria in a tertiary care hospital. Antimicrobial Resistance and Infection Control 2013 2(Suppl 1):P55.
Submit your next manuscript to BioMed Central and take full advantage of:

- Convenient online submission

- Thorough peer review

- No space constraints or color figure charges

- Immediate publication on acceptance

- Inclusion in PubMed, CAS, Scopus and Google Scholar

- Research which is freely available for redistribution
C Biomed Central

\section{Biomed Central}

